\title{
THE ROYAL MILITARY COLLEGE OF CANADA: RESPONDING TO THE CALL FOR CHANGE
}

\author{
Harry J. KOWAL ${ }^{1}$ \\ ${ }^{1}$ The Royal Military College of Canada
}

\begin{abstract}
The Royal Military College of Canada (RMC) has a very proud history of producing quality officers for over 140 years, delivering excellence in education, research and military training that is responsive to the needs of Canada, the Defence community and the ever-changing global security environment. RMC is unique as it is a military unit that is also a recognized university. The primary mission of RMC is to support the Regular Officer Training Plan (ROTP) by educating, developing and inspiring bilingual and fit, ethical leaders to serve the Canadian Armed Forces (CAF) and Canada with distinction.

Since RMC opened its doors in 1876 to the first 18 cadets, there have been a number of studies that have examined the RMC program and that have been the catalyst for positive change. These pivotal moments in history have been indispensable for $R M C$ to remain relevant and continually improve. Of late, there has been a significant amount of attention placed on RMC again, defining another pivotal moment in RMC's history that has become the catalyst for change once again. In October 2016, the Chief of the Defence Staff (CDS), General Jonathan Vance, initiated a Special Staff Assistance Visit (SSAV) to ensure the high standards expected of RMC are upheld and the Auditor General (AG) of Canada, Mr. Michael Ferguson, completed an audit of the ROTP at RMC, the results of which were presented to Parliament in November 2017.
\end{abstract}

Many changes are already in place, but there is more work to do. With a look at governance, the fourpillar program and the call for change, this paper outlines what steps RMC has and will be taken to posture this 'university with a difference' for success for years to come.

Keywords: The Royal Military College of Canada, Special Staff Assistance Visit, Auditor General of Canada, four pillars, core curriculum

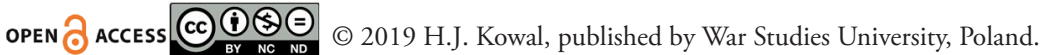

This work is licensed under the Creative Commons Attribution-NonCommercial-NoDerivatives 4.0 License. 


\section{Introduction}

With Canada achieving independence as a country in 1867 and the recall of British troops shortly thereafter, the Canadian government recognized the need for Canada to defend itself (Preston 1969). The absence of British Garrisons meant that "Canada's only defence force, the Active Militia, depended more than ever upon the quality of its officers both for training and for leadership in any operations in which it might become involved" (Preston 1969, p. 9). While the militia continued in operations, the government looked to the future for a permanent defence force and the Royal Military College of Canada (RMC) (Photograph 1, Photograph 2) was established as a means of laying that foundation (Preston 1969).

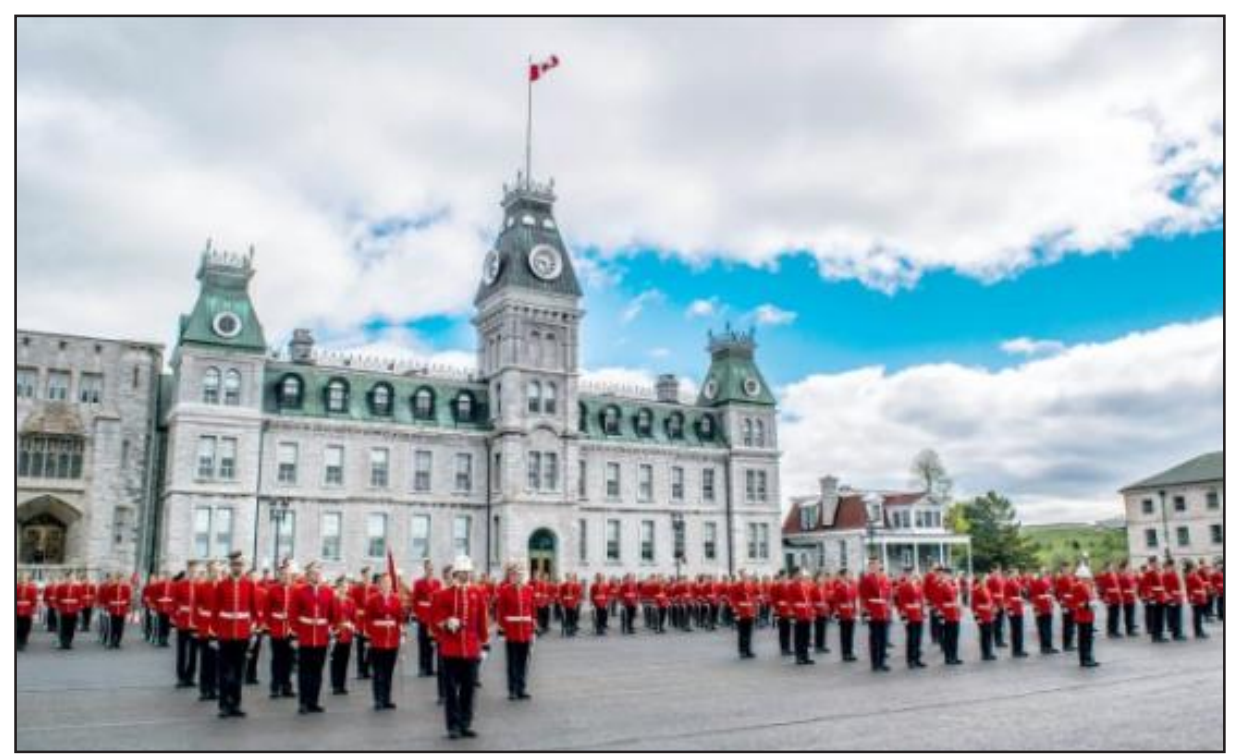

Photograph 1. The Royal Military College of Canada (DND/MDN Canada 2019) 


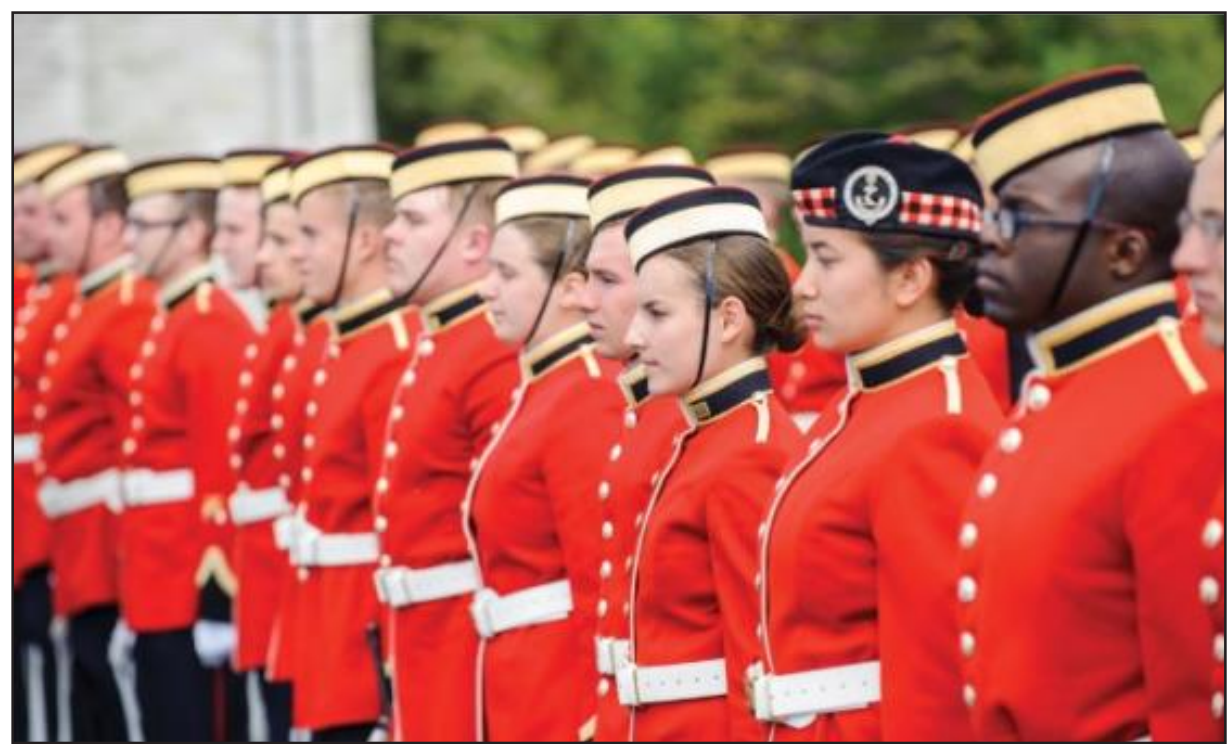

Photograph 2. Cadets at the Royal Military College of Canada (DND/MDN Canada 2019)

The College opened its doors on 1 June 1876 with an enrolment of 18 cadets, remembered fondly as 'The Old Eighteen,' the names of whom are committed to memory and recited by RMC cadets to this day. RMC was created "for the purpose of imparting a complete education in all branches of military tactics, fortification, engineering and general scientific knowledge in subjects connected with and necessary to a thorough knowledge of the military profession and for qualifying officers for command and for staff appointments" (An Act to establish a Military College in one of the Garrison Towns of Canada. Chapter 36 of the Statutes of Canada 1874). One only has to look at the photographs on RMC's Memorial Staircase in MacKenzie Building to appreciate the many sacrifices RMC graduates have made in duty over the years. Notably, RMC graduates have also distinguished themselves in numerous other sectors of Canada with exceptional contributions and leadership in business, politics, professions and academia, not to mention the propensity for them to be selected as astronauts ( 5 out of 14 Canadian astronauts are graduates from RMC).

Over the years, there have been pivotal moments in RMC's history, moments that are remembered because they brought about real change. These changes required strong leadership and the inspiration of strategic minds to help shape RMC into the national institution it has become today. For example, just ten years after RMC opened it was necessary for the Commandant, Colonel G.C. Kitson, to take measures to improve 
discipline and military training to ensure RMC was on the right track (McKenzie 2001). The 1950s saw a dramatic change in the academic program when RMC achieved university status with the authority to grant degrees in Arts, Science and Engineering (Province of Ontario 1959). This achievement was influenced heavily by Colonel W.R. Sawyer, who was serving as the Vice-Commandant and Director of Studies at the time and who from the very beginning believed the RMC degree needed to be different (McKenzie 2001). In 1980, women were accepted for the first time at RMC with the arrival of 32 female cadets, marking a positive step forward for equity, diversity and inclusion at the College and indeed in the Canadian Armed Forces (CAF).

The 1990s were significant for the CAF when cuts to Defence spending resulted in the Forced Reduction Program (Chief Review Services Director General Audit 1997). Royal Roads Military College in Victoria was closed as was Collège militaire royal de SaintJean in Saint-Jean-sur-Richelieu, leaving RMC as the only Military College in Canada. Canada's experience in Somalia at that time impacted officer generation prompting the establishment of new policies that included, "emphasis upon higher level education, to a succession of new senior staff courses to provide higher level professional competencies" (Coombs 2017). Based on recommendations of the Morton Report, the Minister of National Defence (MND), the Honourable Doug Young, decided that all officers in the CAF would require a university degree (Young 1997). Bercuson highlights other positive evolutions for the CAF from this era, including the creation of a defence ethics program and the publication of seminal documents, such as Officership in the $21^{s t}$ Century and Duty With Honour: The Profession of Arms in Canada (Bercuson 2009).

The turn of the century became a time for change for RMC again with the establishment of the Board of Governors (BoG), which commissioned a study to examine the RMC program. The aim of the study was " $[t]$ o ensure for each graduate, a broad-based education, well grounded in the sciences and humanities, with special emphasis being placed on the development of values, ethics and leadership skills needed for responsibilities and service to country" (RMC Board of Governors 1998). Led by former Chief of Defence Staff, General (retired) Ramsey Withers, the study brought forward a number of recommendations, but the Withers' Report is recognized for its support for the military relevant core curriculum, courses directly connected to the Profession of Arms (RMC Board of Governors 1998). The core curriculum is one of the reasons the RMC undergraduate degree programs are different than those in any other Canadian university. 
Throughout its evolution, RMC has been proud of producing quality officers and has been doing so for over 140 years. However, there can never be a time to rest on these laurels and history has shown the intrinsic value of strategic leadership and external reviews. Recently, there has been a significant amount of attention placed on RMC and this has become the catalyst for change once again. The Chief of the Defence Staff (CDS), General Jonathan Vance, became personally involved in upholding the high standards expected of RMC by initiating a Special Staff Assistance Visit (SSAV), the results of which are published in the Maddison-Neasmith Report (Maddison et al., 2017). The Auditor General (AG) of Canada, Mr. Michael Ferguson, also took interest in RMC by initiating an audit "to provide objective information, advice, and assurance to assist Parliament in its scrutiny of the government's management of resources and programs" (Fall Reports of the Auditor General 2017). Both the Maddison-Neasmith Report and the AG Report have made substantial recommendations for improvement at RMC.

And so this has become another pivotal moment in RMC's history, the circumstances of which are providing RMC with tremendous opportunity to produce real and positive change. As RMC's Principal, I can attest that RMC is responding to the call for change, having examined governance, programs and processes through a critical lens and taking the necessary action so that RMC, as a national institution, can continue to provide excellence in education, research and military training, which is responsive to the needs of Canada, the Defence community and the ever-changing global security environment. Much work has begun and many changes are already in place. This paper discusses the call for change and explains how RMC is responding to it.

\section{RMC Governance}

To understand RMC, it is imperative to understand RMC's governance. A unique feature of RMC is that it is a military unit that has the authority to grant university degrees. RMC's authority as a military unit is vested in the National Defence Act (NDA) and its organization and mission is defined by Ministerial Organizational Orders (MOOs) and Canadian Forces Organizational Orders (CFOOs). (Government of Canada n.d.). RMC's authority to confer university degrees comes from Ontario legislation, the Royal Military College of Canada Degrees Act, 1959 (Province of Ontario 1959). 
Accordingly, RMC is recognized as a Canadian University of the Province of Ontario with membership in the Council of Ontario Universities (COU) and with Universities Canada (UnivCan). From a university perspective, the Minister of National Defence (MND) is RMC's President and Chancellor (Government of Canada 1959 and 2001).

The Commandant, normally a Brigadier-General or Commodore, commands RMC as a Commanding Officer, with authorities in accordance with the NDA. From a university perspective, the Commandant is RMC's Vice-Chancellor (Government of Canada 1986) and has the authority to confer degrees in absence of the Chancellor (Province of Ontario 1959). RMC also has a Principal (originally referred to as the Director of Studies) (Province of Ontario 1959) who holds a Governor-in-Council appointment and whose responsibilities have been delegated by the MND through Ministerial Directives, recognizing the Principal as RMC's university representative and Academic Head (Minister of National Defence 2006). The Principal has the authority to confer degrees in absence of the Chancellor and Vice-Chancellor (Minister of National Defence 2009).

Consistent with most Canadian universities, RMC's university governance structure is a bicameral system, balancing "the need for external accountability to the state which financially supports the institution with the need for the participation of the professorate in decisions that focus on academic standards" (Jones 2002, p. F-16). RMC's external accountability is exercised through the chain of command with its next higher headquarters being the Canadian Defence Academy (CDA) and the professorate participates in academic matters through engagement in Faculty Board and Faculty Council, the recommendations from which are brought to the RMC Senate.

\section{The Four-Pillar Program}

The primary mission of RMC is to support the Regular Officer Training Plan (ROTP) by educating, developing and inspiring bilingual and fit, ethical leaders to serve the Canadian Armed Forces and Canada with distinction (Minister of National Defence n.d.). The ROTP-RMC program requires Officer-Cadets to succeed in four interconnected areas: military, academic, bilingualism, and physical fitness. 
- Military: The RMC environment instills a military ethos in Officer-Cadets, underpinning the importance of discipline, teamwork, ethical behaviour and professional responsibility as well as duty, loyalty, integrity and courage as Canadian Military values of the Profession of Arms (Department of National Defence 2009). Officer-cadets are afforded experiential leadership opportunities, guided by mentors and coaches, through the Cadet Wing hierarchy and through their involvement in sports, clubs and recreational activities. They are also provided structured professional development that emphasizes leadership and officership.

- Academic: The RMC undergraduate degree delivered in the ROTP is offered in French and in English and is grounded in the Profession of Arms through a military relevant core curriculum that must be taken by every cadet. The core curriculum is approximately $30 \%$ of the degree requirement and is comprised of courses that address military educational requirements fundamental for a career in the service. Attendance in class is mandatory; it is the Officer-Cadets' place of duty as members of the CAF. The RMC professorate includes serving military faculty members as well as civilian faculty members, some of whom are retired military members. All of RMC's programs are governed by the Council of Ontario Universities Quality Council. In addition, RMC's engineering programs are accredited by Engineer's Canada through the Canadian Engineering Accreditation Board.

- Bilingualism: Communicating in both of Canada's official languages is an important skill for an officer and the foundation achieved at RMC enables graduates to build on their capability. To be commissioned, RMC graduates must achieve a defined level of bilingualism. Second language training is delivered as part of the academic program during the academic year and during the summer months for cadets who have not met the required level of bilingualism. RMC also offers opportunities for students to develop their second language profile beyond the minimum requirement with academic programs such as a minor in Second Language. The cost of delivering second language training earlier in an officer's career is cost effective given the increasing pay scales for officers after graduation.

- Physical Fitness: RMC's Athletic Program is designed so that graduates can be better leaders and can help their subordinates develop in their own fitness. To be commissioned, all RMC graduates must meet a demanding Physical fitness Performance Test (PPT). In addition to fitness classes, education is also provided on mental health and wellness, resilience, and nutrition. Officer-Cadets must also participate in intramural, club or varsity sports. 


\section{The Call for Change}

"A SSAV is a tool used by the senior leadership of the CAF to obtain a full and accurate picture of the state of a unit or function" (Maddison et al. 2017, p. 1). General Vance made the decision to examine RMC using a SSAV to address growing concerns and to "be assured that the climate at $[\mathrm{RMC}]$ is contributing to the healthy development of our future officers and leaders" (Chief of the Defence Staff 2016). Accordingly, he gave the SSAV the mandate "to assess the overall climate, training environment, culture, and Regular Officer Training Plan (ROTP) program construct at the Royal Military College of Canada (RMC), and how these factors impact the morale, welfare and success of the Naval and Officer Cadets (N/OCdts) at the College" (Maddison et al. 2017, p. 1). The SSAV team was led by Vice-Admiral (retired) Greg Maddison and Major-General (retired) David Neasmith. Team members also included legal, medical, spiritual and academic advisors. The SSAV was initiated formally on 19 October 2016 and the final report was published 10 March 2017. Input was received from many stakeholders internal and external to RMC, which "resulted in the SSAV Team interviewing 412 people including 209 N/OCdts, across all academic years and programs; and being in receipt of over 70 e-mail submissions" (Maddison et al. 2017, p. 1). Through its comprehensive approach, the SSAV team made a concerted effort to document the good news stories in addition to areas for improvement.

While the SSAV Team reported that it "assesses that overall RMC is delivering on its mission of producing well educated officers to serve as leaders in the CAF," the team brought forward 79 recommendations for change, which are documented in the Maddison-Neasmith Report (Maddison et al. 2017, p. 52). In addition to the SSAV recommendations, General Vance personally directed 11 additional changes. In the end, a total of 90 recommended improvements were brought forward "...to ensure that the education and training experience continues to evolve so that the N/OCdts' experiences while at RMC remain both challenging and positive to the benefit of the individual and to the benefit of the Canadian Armed Forces (CAF) upon graduation" (Maddison et al. 2017, p. ii). To convey the results, General Vance personally addressed RMC staff, faculty and students on 29 March 2017, making it clear that he accepted the Maddison-Neasmith Report in its entirety and emphasizing that all of the four pillars are essential requirements for commissioning from the ROTP at RMC. Subsequently, 
on 5 April 2017, General Vance promulgated an Initiating Directive for tracking the implementation of the 90 recommendations (Chief of the Defence Staff 2017).

On 21 November 2017, the AG report regarding RMC was tabled in Parliament. The focus of the audit was "whether RMC produced the quality of officers that the Canadian Armed Forces (CAF) needed at a reasonable cost" and "whether DND ensured the proper conduct of Officer-Cadets and staff at RMC" (Fall Reports of the Auditor General 2017). In conducting their investigation, the auditors reviewed documentation internal and external to RMC as well as "key National Defence and RMC policy documents, previous reviews of RMC's training and education of Officer Cadets, and other research documents" (Fall Reports of the Auditor General 2017). The auditors also interviewed faculty, staff and students as well as local health and police services. The AG Report brought forward the following six actionable recommendations to help RMC improve, all of which were endorsed by DND:

- "National Defence should clearly define and strengthen its military training of Officer-Cadets at RMC so that the training is relevant and practical and provides value to operational units. RMC should then integrate the improved military training with the academic education of Officer Cadets;

- National Defence should explore ways to reduce RMC's operating cost per student and consider reducing the number of programs offered;

- National Defence should demonstrate and ensure that the higher standards of the ROTP-RMC are required, that they result in better qualified officers, and that the cost is reasonable;

- National Defence should clearly define the role of the Commandant as the executive authority for day to day operations and long term planning of all aspects of RMC's operations, particularly the ability to oversee and integrate military training and academic programs;

- RMC should ensure that before senior Officer-Cadets are appointed to leadership positions, they demonstrate high standards of conduct and ethical behaviour; and

- RMC should ensure that military training staff have the proper skills and training they need to develop leadership skills among Officer Cadets" (Fall Reports of the Auditor General 2017).

The AG's overall conclusion offered invaluable advice:

"Unless National Defence can resolve the issues identified in this report and the Special Staff Assistance Visit report, the Royal Military College of Canada risks 
becoming just another university and not providing the Canadian Armed Forces with the leaders it requires" (Fall Reports of the Auditor General 2017).

And so the CDS SSAV and the AG audit have defined another pivotal moment in RMC's history with a call for change that needed to be answered. Some observations from the two reviews were similar noting weaknesses in military training and lack of balance between military training and academic programs. The reviews also highlighted areas that needed investment, areas that had been neglected for some time.

\section{RMC Responds}

Since the release of the Maddison-Neasmith Report, RMC has actioned approximately $75 \%$ of the SSAV recommendations, from up-ranking many key leadership positions and reinvesting in language and fitness staff to relaxing the walking-out dress policy and reinstating study/silent hours, to name but a few. As Tattersall (2017) reported, some of the improvements had a much more personal benefit to the Officer-Cadets, including the opening of a Care Delivery Unit (CDU) on RMC grounds with "primary care health services, dental care coordination, mental health $(\mathrm{MH})$ services, pharmacy, and physiotherapy" (Tattersall 2017, pp. 56-59). The impact of the CDU for the OfficerCadets has been profound because of the extended hours that included weekend services and more importantly, it means they can now seek support discreetly and no longer have to wait for a bus that caused them to miss portions of their very busy schedules.

In terms of reinforcing the four-pillar program, the Officer-Cadets themselves have responded to the challenge with a renewed motivation in Second Language classes and by increasing their fitness levels. To help continue to posture our students for success, RMC established a College Success Centre, with a Grand Opening that took place February 2018. The Success Centre has the mission to respond to the needs of our students by providing help in a number of different areas, such as writing and math but it also serves as a focal point to guide students to the expertise needed, including fitness, mental health and social services.

Some of the SSAV recommendations involve infrastructure and therefore final implementation of all recommendations is still expected to take some time. Hence, while much work has been completed, there is still more work to be done before all 
90 recommendations have been addressed. Progress, however, is being monitored by RMC through a Performance Management Framework as part of the SSAV Implementation Action Plan. RMC's commitment to change is also reflected in the recently published RMC Strategic Plan 2023 (Royal Military College of Canada 2019).

DND's response to the recommendations made by the $A G$ is documented in the Detailed Action Plan for Office of the Auditor General Report Recommendations (Detailed Action Plan 2017). The AG report was also presented to Parliament's Standing Committee on Public Accounts (SCoPA), after which seven additional reports were recommended to be promulgated by DND. The Detailed Action Plan and the reports to SCoPA address improvements to training and education, behaviour of Officer-Cadets in leadership positions, skills and training for military staff, governance and the position of the Commandant, demonstrating the need for higher standards as well as cost efficiencies and cost comparisons (Sorenson 2017). Here is RMC's progress and some of the ways that RMC has made and is making real change as a result of the AG audit.

There has been a comprehensive review of military training at RMC, with many changes already in place. The training program is now aligned more closely with the CAF Leadership Development Framework and Officer-Cadets now receive individualized assessments focussed on strengths and weaknesses. Coaching, mentoring and oversight has been enhanced by raising the ranks of key training wing personnel so that OfficerCadets can benefit from enhanced experience and skills that come with higher ranks (Department of National Defence 2018, Response to Recommendation 1).

Military training has also been enhanced with the use of operational scenarios, such as "conducting investigations, conducting military planning and handling subordinates in situations involving military discipline and the military justice system" (Department of National Defence 2018, Response to Recommendation 1, pp. 1-2). In addition, summer training has also been reviewed and the experience gained from 2018 has informed the placements for summer 2019 to ensure experiential learning opportunities are optimized for Officer-Cadets. The summer experiences will be reviewed annually to ensure Officer-Cadets receive the best training possible during the summer months (Department of National Defence 2018, Response to Recommendation 1).

"RMC is improving the coordination between military and academic programs through regular weekly meetings of the Military, Academic and Athletic Wings to ensure alignment of all activities, respect for Commandant's priorities as well as opportunities 
for synergies" (Department of National Defence 2018, Response to Recommendation 1, p. 2). From a university perspective, the RMC Senate struck a Four-Pillar Review Committee with the aim of ensuring all four pillars remain essential. The committee will inform a Senate decision by summer 2019 regarding upholding the four pillars as they relate to the RMC degree. In addition, a sub-committee of Faculty Board has been created to examine the core curriculum to determine the changes necessary to ensure it remains relevant to the Profession of Arms and continues to align with the needs of the service. At the classroom-level, RMC continues to update course material to ensure the integration of military learning. RMC's third-year course on Organizational Behaviour and Leadership is a good example of this where both Operation Honour (preventing harmful and inappropriate sexual behaviour) and the Defence Policy are already incorporated in the course material with topics including diversity, biases, perception, values, equity and culture (Department of National Defence 2018, Response to Recommendation 1).

RMC has also taken measures to reinforce the mandatory attendance policy and to ensure periods of time are protected for both academic education and military training. Study hours are protected for academics and a new approval process has been implemented for extra-curricular academic activities to minimize their impact on military activities. In our continuing efforts to familiarize civilian personnel to RMC's unique military environment, a new Faculty and Staff Orientation Program has been implemented and new Faculty and Staff are encouraged to participate in the annual Battlefield Tour and summer visits to Bases and Wings (Department of National Defence 2018, Response to Recommendation 1).

With regards to the AG's concern for the conduct and behaviour of senior OfficerCadets appointed to leadership positions, the selection process for these appointments has already been adjusted to be more merit-based and to require the Commandant's approval. Higher ranked leaders and mentors guiding Officer-Cadets throughout their leadership development will ensure the highest standards of conduct and ethical behaviour, especially before appointment to a leadership position (Department of National Defence 2018, Responses to Recommendations 2, 3, 5, 6 and 7). It is important to understand, however, that leadership positions for Officer-Cadets at RMC are developmental opportunities and, therefore, the potential still exists for mistakes to be made. To the Princeton graduating class of 2013, Ben Bernanke offered the following, "Nobody likes to fail but failure is an essential part of life and of learning. If your 
uniform isn't dirty, you haven't been in the game."' It is my belief and my experience that many of the life lessons learned on the RMC peninsula have come about by learning from mistakes. This is not to suggest by any means that RMC tolerate poor conduct or condone unethical behaviour. Each case must be examined individually and the response from RMC to any such occurrences must be made in the best interests of the institution and of the student. In this way, all experiences at RMC can be learning moments.

The recommendation from the AG regarding the position of Commandant is consistent with the Maddison-Neasmith Report and the length of command tour for the Commandant has already been increased to three years (Department of National Defence 2018, Responses to Recommendations 2, 3, 5, 6 and 7). From a governance perspective, RMC established an internal governance committee, which met multiple times over the past year and produced a report summarizing its recommendations. The committee concluded that "RMC's governance as a Military Unit and a provincial chartered university is sound but there are a number of seams and gaps that need to be addressed." (Royal Military College of Canada 2018). The committee agreed, however, with the SSAV and AG that the Queen's Regulations and Orders for the Canadian Military Colleges (QRCanmilcols) are in need of an update. The recommendations of this committee were staffed to CDA HQ to be incorporated in the CDA-led governance Working Group. At a more strategic level, recommendations on governance have been addressed by the CDS, who now chairs a newly established Council of Canadian Defence Academy Commandants. In addition, the Commander CDA now holds membership on Armed Forces Council, the senior advisory council to the CDS. These new reporting and information structures will enhance the visibility of training and education at RMC to the highest level in the CAF (Department of National Defence 2018, Responses to Recommendations 2, 3, 5, 6 and 7).

The AG raised concern for the value of the RMC program, stating "it is difficult to make a direct link between graduation from RMC and military career success" (Fall Reports of the Auditor General 2017). In response, DND committed to conducting "an in-depth analysis on the effectiveness of the ROTP program at RMC, including factors such as graduation, retention, career development and progression rates, for senior CAF Officers (Major/Lieutenant Commander to General/Admiral) to demonstrate the

1 Ben Bernanke is an economist and tenured professor at Princeton who served two terms as Chairman of the Federal Reserve for the central bank of the United States (Weissmann 2013). 
value of the ROTP at RMC” (Detailed Action Plan 2017). Accordingly, a scientific study was conducted by the Director General Military Personnel Research and Analysis (DGMPRA) branch, which confirmed, for the sample population analyzed, that being a Canadian Military College (CMC) graduate did result in faster progression, lower attrition and over representation at the rank of Lieutenant-Colonel (Commander) and above. The study also acknowledged RMC's four-pillar program in helping prepare graduates for service as well as highlighted the significant value of practical military leadership training and early second language proficiencies (Department of National Defence 2018, Internal document).

While this analysis speaks volumes for the benefits of RMC-ROTP program, I am reminded of the expression, "Not everything that can be counted counts, and not everything that counts can be counted" (Cameron 1963, p. 13). In addition to the four pillar program, there is unquestionable value to the CAF in having future leaders immersed together in a bilingual, military environment for four years of university education. The experience not only instills a military ethos with ethical values of Truth, Duty, and Valour, but it enables the building of a network and true friendships that last lifetimes and that are readily leveraged for the benefit of the organization within which RMC graduates serve.

The cost per ROTP student was highlighted as a concern by the AG and, in response, DND committed to reviewing and validating the reported costs and to making RMC as cost effective as possible (Detailed Action Plan 2017). Accordingly, RMC has initiated a costing study and a review of programs to identify opportunities for cost savings and cost efficiencies. RMC's focus also includes an evolution of academic programs to ensure their relevance and that they continue to meet the education and research needs of the service. The costing study and review are underway and the results are not available for this paper. However, RMC has moved forward on initiatives such as optimizing the number of ROTP students in residence and in the classroom as well as creating opportunities to grow the number of distance students (Department of National Defence 2018, Responses to Recommendations 2, 3, 5, 6 and 7). These initiatives have already resulted in cost savings to hiring sessional instructors and an increase in the student base to reduce the cost per student. DND does recognize and accept, however, that there is a premium associated with producing an RMC graduate (Detailed Action Plan 2017). RMC may cost more but, RMC also delivers more. 


\section{More to the RMC Experience}

Speaking of more, while the AG report focussed only on the ROTP-RMC program, there is so much more to the RMC experience. RMC also delivers undergraduate education at a distance as well as graduate education in residence and at a distance. Our students include Regular and Reserve Force members (officers and non-commissioned members) and their spouses as well as civilian members of the Department of National Defence. RMC's undergraduate distance programs include a Bachelor of Arts (BA) and a Bachelor of Military Arts and Science (BMASc). At the graduate level, RMC delivers masters and doctorate degrees in Arts, Science and Engineering, including War Studies, Business Administration (MBA), Public Administration (MPA) and Defence Studies (MDS) (Royal Military College of Canada 2014).

RMC delivers specialty education such as the Non-commissioned Member Executive Professional Development Program (NEPDP), the Army Technical Warrant Officer (ATWO) program, and the Army Technical Staff Officer (ATSO) program. There are numerous short courses delivered in a broad spectrum of areas that contribute to technical education and support technical investigations. RMC also delivers a one-year program for Aboriginal students (the Aboriginal Leadership Opportunity Year (ALOY)).

RMC's research facilities include a SLOWPOKE II nuclear reactor, wind tunnels, an anechoic chamber, an observatory and a cyber-lab. RMC professors conduct research and provide expert advice in many disciplines of arts and the humanities, science and engineering. Some of RMC's research is classified or of operational significance, and at times conducted in direct support of operations. These experiences fuel our professors' passions and enhance their expertise and enthusiasm, which they bring into the classroom, significantly enriching the learning environment.

However, here we are, at another pivotal moment in RMC's history and it is a time for change. Consequently, the RMC learning environment is evolving. Both the MaddisonNeasmith Report and the AG Report have made substantial recommendations for improvement, igniting a renewed interest and investment in RMC not seen in years and providing RMC tremendous opportunity to produce real and positive change, change that is essential for RMC's future. RMC has listened and the messages are clear. RMC is recognized as being unique but needs to continue to evolve so as to remain relevant and continue to meet the needs of our students and the service. All four pillars and the 
core curriculum are essential as they define why the RMC experience is different. RMC's accountability and the responsible stewardship of resources are paramount because they give our external stakeholders the confidence that RMC can execute its mission within the resources given. RMC's programs and processes must be as cost effective as possible to ensure RMC's value proposition is affordable.

It has been a difficult period of time for the leadership at RMC, but in the words of Albert Einstein, "In the middle of difficulty lies opportunity." The results of the recent reviews have been inspiring because they recognize RMC as an institution of excellence and worthy of investment. In responding to the call for change, I am confident that the action RMC is taking today will ensure RMC's success for years to come.

\section{References}

An Act to establish a Military College in one of the Garrison Towns of Canada. Chapter 36 of the Statutes of Canada, 1874.

Bercuson, D.J., 2009. Up From The Ashes: The The Canadian Forces After The Somalia Affair. Canadian Military Journal, 9 (3), 31-39.

Cameron, W., 1963. Informal sociology: A casual introduction to sociological thinking. New York: Random House.

Canada. Department of National Defence, 2017. Strong, secure, engaged - Canada's defence policy. Ottawa: National Defence.

Chief of the Defence Staff, 2016. Chief of the Defence Staff (CDS) Letter to the Minister: Staff Assistance Visit to Royal Military College of Canada.

Chief of the Defence Staff, 2017. Chief of the Defence Staff (CDS) Directive for Royal Military College of Canada (RMC) Special Staff Assistance Visit (SSAV) Action Plan.

Chief Review Services Director General Audit, 1997. Audit of force reduction program. Ottawa.

Coombs, H., 2017. 25 Years after Somalia: How it Changed Canadian Armed Forces Preparations for Operations.

Department of National Defence, 2009. Duty With Honour: The Profession of Arms in Canada. Kingston: Canadian Defence Academy.

Department of National Defence, 2018. Deputy Minister letter to the: Government response to the Forty-Sixth Report of Standing Committee on Public Accounts, entitled Report 6, Royal Military College of Canada-National Defence, of the Fall 2017 Reports of the Auditor General of Canada: Response to Recommendation 1 due 17 September 2018, [online]. Available from: https://www.ourcommons.ca/content/Committee/421/PACP/WebDoc/ WD10008847/421_PACP_reldoc_PDF/PACP_DepartmentOfNationalDefence-Rec1-e. pdf [Accessed 9 Sept 2018]. 
Department of National Defence, 2018. Deputy Minister letter to the: Government response to the Forty-Sixth Report of Standing Committee on Public Accounts, entitled Report 6, Royal Military College of Canada-National Defence, of the Fall 2017 Reports of the Auditor General of Canada: Responses to Recommendations 2, 3, 5, 6, and 7 due 31 December 2018, [online]. the House of Commons website. Available from: https://www.ourcommons.ca/ content/Committee/421/PACP/WebDoc/WD10285206/421_PACP_reldoc_PDF/42_1_ PACP_DepartmentOfNationalDefence-Rec2-3-5-6-7-e.pdf [Accessed 12 Dec 2018].

Department of National Defence, 2018. Internal document, 1150-1 (DGMPRA), "Distribution of Scientific Brief: Highlights of Studies Comparing Officers from Different Entry Plans."

Detailed Action Plan for Office of the Auditor General Report Recommendations, Fall Reports of the Auditor General of Canada to the Parliament of Canada, 2017. Report 6-Royal Military College of Canada-National Defence, [online]. Available from: http://www. ourcommons.ca/Content/Committee/421/PACP/WebDoc/WD8148750/Action_ Plans/70-DepartmentOfNationalDefence-e.pdf [Accessed 15 Mar 2018].

Fall Reports of the Auditor General of Canada to the Parliament of Canada, 2017. Report 6Royal Military College of Canada-National Defence. [online]. Available from: http://www. oag-bvg.gc.ca/internet/English/parl_oag_201711_06_e_42671.html [Accessed 30 Nov 2017].

Government of Canada, 1959. Queen's Regulations and Orders for Canadian Service Colleges.

Government of Canada, 1986 and 2001. Queen's Regulations and Orders for the Canadian Military Colleges.

Government of Canada, n.d. National Defence Act (R.S.C., 1985, c. N-5). Justice Laws Website. Jones, G.A., 2002. The Structure of University Governance in Canada: A Policy Network Approach. In: Governing Higher Education: National Perspectives on Institutional Governance. Dordrecht: Springer, 213-234.

Maddison, G.R., Neasmith, D.G., Tattersall, V.C., Bouchard, A.M.C., et al, 2017. Special Staff Assistance Visit, report on the climate, training environment, culture and Regular Officer Training Plan (ROTP) program at the Royal Military College of Canada. Kingston: Government of Canada Publications, [online]. Available from: https:/www.canada.ca/content/dam/dndmdn/documents/reports/20170329-rmc-ssav-report-final.pdf [Accessed 11 Apr 2017].

McKenzie, R., 2001. 'Military Knowledge and Scientific Pursuits...' Royal Military College of Canada: The First 125 Years. Canadian Military Journal, 2 (3), 13-20.

Minister of National Defence, 2006. Ministerial Directives Respecting the Principal of the Royal Military College of Canada. Minister of National Defence.

Minister of National Defence, 2009. Letter to Commandant RMC dated 22 June 2009. Minister of National Defence.

Minister of National Defence, n.d. Ministerial Organization Order 2007070 (Royal Military College of Canada). Government of Canada.

Preston, R., 1969. Canada's RMC: A history of the Royal Military College. Toronto: University of Toronto Press.

Province of Ontario, 1959. The Royal Military College of Canada Degrees Act, [online]. Available from: https://www.cicic.ca/docs/postsec/RMCC_degrees_act_1959.pdf [Accessed 16 Aug 2017]. 
RMC Board of Governors, 1998. Report to the Board of Governors by the Withers' Study Group, "Balanced Excellence: Leading Canada's Armed Forces in the New Millennium" Department of National Defence internal document.

Royal Military College of Canada, 2014. Inspiring Excellence: The Strategic Plan for the Academic

Wing at the Royal Military College of Canada, [online]. Available from: https://www.rmcccmrc.ca/sites/default/files/sfaw-csee-eng.pdf. [Accessed 8 Aug 2018].

Royal Military College of Canada, 2018. RMC Internal report, "Report of the RMC Governance Committee".

Royal Military College of Canada, 2019. Royal Military College of Canada Strategic Plan 2023, [online]. Available from: https://s3.amazonaws.com/everitas/2019/04/RMC-Strategy-PlanBooklet-EN-Jan-4-2019.pdf [Accessed 22 Apr 2019].

Sorenson, K., 2017. Report 6, Royal Military College of Canada : National Defence, of the 2017 fall reports of the Auditor General of Canada : report of the Standing Committee on Public Accounts. Ottawa: House of Commons, [online]. Available from: https://www.ourcommons.ca/ Content/Committee/421/PACP/Reports/RP9851890/pacprp46/pacprp46-e.pdf [Accessed 5 Nov 2018].

Tattersall, V., 2017. Royal Military College of Canada Special Staff Assistance Visit Update. Canadian Military Journal, 18 (1).

Weissmann, J., 2013. Ben Bernanke to Princeton Grads: The World Isn't Fair (and You All Got Lucky) - The Atlantic [online]. Available from: The Atlantic, https:/www.theatlantic.com/ business/archive/2013/06/ben-bernanke-to-princeton-grads-the-world-isnt-fair-and-youall-got-lucky/276471/ [Accessed 13 Oct 2018].

Young, D., 1997. Report to the Prime Minister on the Leadership and Management of the Canadian Forces.

\section{Author:}

Harry J. Kowal, PhD

The Royal Military College of Canada 